Łukasz Bojko (Wrocław)

\title{
Proces Bolesława Kontryma. Sądownictwo Polski Ludowej w latach 1944-1955: zarys problemu
}

Sądownictwo i prokuratura stały się w okresie stalinowskim istotnym narzędziem władzy komunistycznej i stworzonej przez nią machiny terroru. Dopełniały one proces eliminacji przeciwników politycznych poprzez prawną i formalno-procesową legitymizację bezprawnej i zbrodniczej działalności operacyjno-śledczej organów bezpieczeństwa państwa, zarówno bezpieki cywilnej (Ministerstwo Bezpieczeństwa Publicznego), jak i wojskowej (Główny Zarząd Informacji Wojska Polskiego). Genezy komunistycznego sądownictwa należy doszukiwać się już w treści Manifestu Polskiego Komitetu Wyzwolenia Narodowego ogłoszonego 22 lipca 1944 r. Manifest ten deklarował m.in., że „zadaniem niezawisłych sądów polskich będzie zapewniać szybki wymiar sprawiedliwości. Żaden niemiecki zbrodniarz, żaden zdrajca narodu nie może ujść kary". Manifest zawierał także takie sformułowania, jak: „demokratyczne swobody nie mogą jednak służyć wrogom demokracji” albo: „organizacje faszystowskie, jako antynarodowe, tępione będą z całą surowością prawa", przy czym nie precyzował pojęć takich, jak „wróg demokracji”, „organizacja faszystowska” albo „zdrada narodu polskiego”, tworząc tym samym dla władzy komunistycznej możliwość dowolnej ich interpretacji. Dowodem tego były już pierwsze dni istnienia tzw. Polski Lubelskiej, na terenie której działalność komunistów, wymierzona w struktury i członków Polskiego Państwa Podziemnego, zwłaszcza żołnierzy Armii Krajowej, wskazywała, że Manifest PKWN nie był jedynie wyrazem komunistycznej propagandy i deklaracją intencji, ale stanowił wykładnię dla różnych form terroru, prześladowań oraz represji sądowo-karnych ${ }^{1}$.

1 J. Poksiński, Stalinowskie represje wobec oficerów Wojska Polskiego 1945-1956, Warszawa 1992, s. 11-12. 
Twórcy Manifestu PKWN zapewniali, że władza sądownicza sprawowana będzie zgodnie z zapisami konstytucji marcowej z 1921 r. (komuniści odrzucali konstytucję kwietniową z 1935 r., uznając ją za faszystowską²), która wyraźnie i jednoznacznie oddzielała władzę sądowniczą od ustawodawczej i wykonawczej ${ }^{3}$. Od początku jednak zasada konstytucyjnej niezależności i niezawisłości sędziowskiej pozostawała pustym frazesem, gdyż była nie do pogodzenia z sowiecką doktryną prawa karnego $0^{4}$ i leninowskim spojrzeniem na rolę sądów w państwie komunistycznym, zgodnie z którym „sąd powinien terror uzasadnić i zalegalizować go pryncypialnie, jasno, bez fałszu i bez upiększenia"5. Dobitnie ideologiczno-polityczną rolę sądownictwa początków Polski Ludowej podkreślił Bolesław Bierut, który 27 sierpnia 1946 r., jako przewodniczący (prezydent) Krajowej Rady Narodowej (KRN), napisał w decyzji odmawiającej prawa łaski skazanemu 17-letniemu Franciszkowi Borsukowi, że: „w okresie napiętych walk społecznych, rolą sądownictwa jest walka o wychowanie społeczne i wyeliminowanie elementów

${ }^{2}$ Negacja ta wynikała także z racji czysto politycznych. Nieuznawanie konstytucji kwietniowej w naturalny sposób pociągało za sobą odmawianie legalności Polskiemu Państwu Podziemnemu oraz rządowi na uchodźstwie. Jednocześnie zarówno KRN, jak i PKWN uznawały całe ustawodawstwo sprzed 1 września $1939 \mathrm{r}$.

${ }^{3}$ Art. 2: „Władza zwierzchnia w Rzeczypospolitej Polskiej należy do Narodu. Organami Narodu w zakresie ustawodawstwa są Sejm i Senat, w zakresie władzy wykonawczej - Prezydent Rzeczypospolitej łącznie z odpowiedzialnymi ministrami, w zakresie wymiaru sprawiedliwości niezawisłe Sądy”. Art. 77: „Sędziowie są w sprawowaniu swego urzędu sędziowskiego niezawiśli i podlegają tylko ustawom. Orzeczenia sądowe nie mogą być zmienione ani przez władzę ustawodawczą, ani przez władzę wykonawczą". Dz.U. 1921 nr 44 poz. 267, Ustawa zasadnicza z 17 marca 1921 roku.

${ }^{4}$ Praworządność komunistyczna wymagała, aby sądy kierowały się rewolucyjną (socjalistyczną) świadomością i sumieniem, przy czym nie precyzowano, co oznaczają te pojęcia. Były one natomiast czołowymi klauzulami generalnymi nowego porządku prawnego. Podstawowym zadaniem sowieckiego prawa karnego była walka z tymi, którzy naruszali nowe zasady współżycia, kształtujące się przejściowo w okresie dyktatury proletariatu. M. Mohyluk, Wacław Makowski o radzieckim prawie karnym, „Miscellanea Historico-Iuridica” 2009, t. VII, s. 86-88. Czołowy prokurator stalinowski, Andriej Wyszyński, pisał m.in., że , zadaniem radzieckiego, socjalistycznego prawa jest przełamanie oporu wrogów klasowych i ich agentur, zabezpieczenie budownictwa socjalistycznego, wzmocnienie nowych, socjalistycznych stosunków społecznych oraz całego radzieckiego ładu prawnego". J. Poksiński, Sędziowie Wojskowi w latach 1944-1956: próba zarysowania problemu, „Niepodległość i Pamięć” 1997, r. IV, nr 1(7), s. 37. Z kolei Leszek Kołakowski pisał, że „w najważniejszych punktach prawo totalitarne musi być mgliste i nieokreślone, tak że faktyczne jego zastosowanie zależy od arbitralnych i zmiennych decyzji władzy wykonawczej, a każdy obywatel w każdym niemal momencie może uchodzić za przestępcę". L. Kołakowski, Czy diabet może być zbawiony i 27 innych kazań, Kraków 2006, s. 352.

5 Ibidem, s. 46. Działacz SDKPiL Mieczysław Kozłowski uznał prawo karne za najważniejszy element w procesie eliminacji wrogów klasowych. Źródłem prawa karnego jest jedynie wola klasy sprawującej władzę i zdolnej do narzucania swej woli pozostałym siłom społecznym. A. Bosiacki, Utopia, władza, prawo. Doktryny i koncepcje prawne ,, bolszewickiej” Rosji 1917-1921, Warszawa 1999, s. 218. 


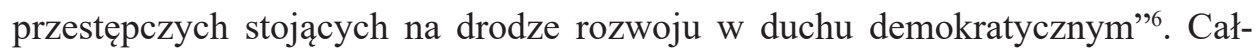
kowitej dyspozycyjności sądów i ich skuteczności w „walce o wyeliminowanie elementów przestępczych" dowodzi także treść późniejszej uchwały Biura Politycznego KC PZPR z dnia 20 marca 1951 r. o pracy organów służby sprawiedliwości w wojsku, w której stwierdzono, że „organy sądownictwa wojskowego wykazały poważną pomoc w umacnianiu władzy ludowej, przyczyniając się do unieszkodliwienia wrogów Polski Ludowej, szpiegów, dywersantów, szerzycieli wrogiej propagandy, członków ośrodków kontrrewolucyjnych i agentury angloamerykańskiego imperializmu"7.

W okresie wczesnego stalinizmu w Polsce, a więc pierwszych lat powojennych (1945-1947), władzy komunistycznej zależało na zachowaniu pozorów legalizmu, demokratyzmu i praworządności. Postawa ta - dodajmy, czysto taktyczna i kalkulacyjna - była wynikiem oceny sytuacji wewnętrznej i międzynarodowej. Komuniści polscy wówczas dopiero umacniali swą władzę, istniała legalna opozycja polityczna i poakowskie podziemie zbrojne, a podział świata na obóz kapitalistyczny i obóz komunistyczny nie był jeszcze rozstrzygnięty. W tych realiach starano się pozornie zachować ciągłość państwa polskiego, także oczywiście na płaszczyźnie prawnej. Utrzymano więc całe przedwojenne powszechne ustawodawstwo cywilne i karne, w tym kodeks postępowania karnego z 1928 r. i kodeks karny z 1932 roku. Oczywiście prawo II RP nie nadawało się do osiągania celów wyznaczonych przez władzę komunistyczną, toteż podjęto szereg działań zmierzających do przekształcenia sądownictwa w sprawne narzędzie wspomagania procesu sowietyzacji Polski. Celem niniejszego artykułu nie jest szczegółowa charakterystyka tych zmian, zatem ograniczmy się do podkreślenia istotnego dla dalszej części artykułu faktu, iż przedwojenne ustawodawstwo karne było uzupełniane o uchwalane przez władzę komunistyczną dekrety mające charakter wyraźnie represyjny i rozrachunkowy wobec tych wszystkich, których uznano za wrogów Polski Ludowej. Wśród tych dekretów można wymienić np. niesławną „sierpniówkę", a więc dekret PKWN z 31 sierpnia 1944 r. o wymiarze kary dla faszystowsko-hitlerowskich zbrodniarzy winnych zabójstw i znęcania się nad ludnością cywilną i jeńcami oraz dla zdrajców Narodu Polskiego ${ }^{8}$ albo niezwykle

6 J. Poksiński, „My, sędziowie, nie od Boga...” Z dziejów Sądownictwa Wojskowego PRL 1944-1956, Warszawa 1996, s. 32.

7 Uchwała Biura Politycznego KC PZPR z dnia 20 marca 1951 r. o pracy organów służby sprawiedliwości w wojsku, A. Paczkowski (red.), Kierownictwo PPR i PZPR wobec wojska. Dokumenty do dziejów PRL, Warszawa 2003, s. 237.

${ }^{8} \mathrm{~W}$ atmosferze rozliczeń zbrodniarzy niemieckich, dekret ten w pewnym stopniu wychodził naprzeciw oczekiwaniom społeczeństwa polskiego. Dekret ten posłużył jednakże do zohydzania żołnierzy AK, ukazywania ich jako sojuszników hitlerowców, gdyż przez zawarte w art. 1 Dekretu pojęcie „działania na rękę władzy okupacyjnej niemieckiej” rozumiano także zwalczanie organizacji komunistycznych (zwłaszcza PPR, GL-AL) i partyzantki sowieckiej. Każdy przejaw działalności 
surowy dekret PKWN z 30 października 1944 r. o ochronie państwa9. Te i pozostałe dekrety były aktami prawnymi niemającymi wiele wspólnego z demokracją i praworządnością. Były za to bardziej prawem stanu wyjątkowego, narzuconym całemu społeczeństwu, wymierzonym we wroga wewnętrznego i pozwalającym uzasadnić terror wyższymi racjami ideologicznymi ${ }^{10}$.

Zupełnie odmienne podejście prezentowali komuniści wobec sądownictwa wojskowego. 29 października 1944 r. na posiedzeniu Biura Politycznego KC PPR, ówczesny sekretarz generalny partii, Władysław Gomułka, powiedział m.in.: „myśmy sprawę wojska znacznie zaniedbali” i: „,wojsko jest podstawową siłą aparatu państwowego. Musimy mieć to wojsko w ręku, inaczej ujmie je ktoś inny i obróci przeciwko nam [...]. Sprawa wojska jest dla nas przede wszystkim zagadnieniem politycznym i dlatego Partia musi nie tylko ingerować w sprawy wojskowe, ale kierować wojskiem" "11. Dużą część posiedzenia poświęcono Armii Krajowej, którą uznano za element wrogi i antydemokratyczny w przeważającej masie, a do tego dominujący w najważniejszych ogniwach wojskowych, wobec tego postanowiono, że bezwzględnie musi on zostać usunięty. Politykę wobec żołnierzy AK ustalono na posiedzeniach Wydziału Wojskowego w dniach 18 grudnia 1944 r. i 12 stycznia 1945 r. Zgodnie z przyjętymi zasadami, postanowiono akowców do wojska nie przyjmować, a winnych „zbrodni bratobójczych" przekazać sądom. Zadecydowano także oczyścić szkoły wojskowe $\mathrm{z}$ wrogich akowskich elementów i nie wydawać promocji absolwentom szkół oficerskich, którzy są ,ideologicznie związani” z AK. Politykę wobec AK władza komunistyczna nieco złagodziła po ustaleniach plenum KC PPR w maju 1945 r., zgodnie z którymi otwarty dostęp do wojska mieli jedynie ci akowcy, którzy „walczyli o wolność z Niemcami i z nienawiści do nich”. Z kategorii tej zostali wyłączeni ci żołnierze AK, którzy „,brali udział w przeciwdemokratycznej i przeciwradzieckiej propagandzie”. Bezwzględnie zamknięto służbę w woj-

AK mógł być przez komunistów zinterpretowany jako czyn rzekomo korzystny dla władzy hitlerowskiej, a tym samym zdradziecki wobec Narodu Polskiego. Dz.U. 1944 nr 4 poz. 16.

${ }^{9}$ Wszystkie 11 materialnoprawnych artykułów Dekretu przewidywało karę śmierci. Kara śmierci groziła temu, kto „zakłada związek, mający na celu obalenie demokratycznego ustroju Państwa Polskiego" albo temu, kto w nim uczestniczy. Karze śmierci podlegał także ten, kto przykładowo: „utrudnia wprowadzenie w życie reformy rolnej” lub „,bez prawnego zezwolenia władzy wyrabia, przechowuje, nabywa lub zbywa broń, amunicję”. Szczególnie w żołnierzy AK godził artykuł 8 ustanawiający karę śmierci dla tego, „kto uczestniczy w związku mającym na celu przestępstwo albo którego istnienie, ustrój lub cel ma pozostać tajemnicą". Karze śmierci podlegała także osoba, która wiedziała o przestępstwie uregulowanym w Dekrecie i „w porę” nie doniosła o nim władzy. Dz.U. 1944 nr 10 poz. 50.

${ }_{10}$ J. Poksiński, Stalinowskie represje..., s. 21.

${ }^{11}$ A. Paczkowski (red.), Kierownictwo PPR..., s. 17. 
sku znienawidzonym członkom Narodowych Sił Zbrojnych (NSZ) i osobom z kręgów kierowniczych $\mathrm{AK}^{12}$.

Usuwanie z szeregów wojska osób z proweniencją akowską i przedwojenną następowało równolegle $\mathrm{z}$ uzupełnianiem kadr sądownictwa wojskowego i prokuratury wojskowej o absolwentów Oficerskiej Szkoły Prawniczej w Jeleniej Górze $^{13}$ (nie należy mylić tej instytucji z Centralną, a następnie Wyższą Szkołą Prawniczą im. Teodora Duracza w Warszawie). Jednocześnie z polityką kadrową i procesem intensywnej indoktrynacji wojska zachodziły zasadnicze przeobrażenia o charakterze instytucjonalnym, strukturalnym i orzeczniczym w wojskowym wymiarze sprawiedliwości, czego najistotniejszymi dowodami był dekret PKWN z 23 września 1944 r. o ustroju sądów wojskowych i prokuratury wojskowej, wprowadzający nowy, drastycznie represyjny Kodeks Karny Wojska Polskiego $(\text { KKWP })^{14}$ i tym samym derogujący przedwojenny Kodeks Karny Wojska Polskiego z 1932 roku. O ściśle inkwizycyjnym charakterze procesu sądowego, którego oskarżony był przedmiotem, a nie podmiotem, przesądził Kodeks Wojskowego Postępowania Karnego uchwalony 23 czerwca 1945 r. Podporządkował on całe postępowanie przygotowawcze prokuratorowi, który w dowolnej chwili mógł or-

12 Ibidem, s. 15-29.

${ }_{13}$ Oficerska Szkoła Prawnicza została utworzona na mocy rozkazu Ministra Obrony Narodowej, marszałka „Roli” Żymierskiego. Otwarta została w dniu 22 lipca 1948 r., w rocznicę powstania PKWN. Istniała w latach 1948-1954. Początkowo instytucja ta miała siedzibę w Warszawie, rok później została przeniesiona do Jeleniej Góry, a od 1951 r. do Mińska Mazowieckiego. Kandydatom nie stawiano żadnych wymogów odnośnie wykształcenia, co skutkowało tym, że wielu kursantów nie posiadało nawet podstawowego wykształcenia (nie ukończyli szkoły powszechnej). W Szkole prowadzono rozmaite kursy, trwające od 2,5 miesiąca do 24 miesięcy. Kurs podstawowy trwał początkowo rok, potem wydłużono go do 18 miesięcy. Program nauczania obejmował przedmioty ogólne, wojskowe, prawnicze i polityczne. Absolwenci mieli możliwość podjęcia studiów na wydziałach prawa uczelni wyższych bez konieczności przystępowania do egzaminów wstępnych. Szacuje się, że Szkołę ukończyło ok. 600 słuchaczy. W 1954 r. Szkołę zamknięto, a w jej miejsce powstał Fakultet Wojskowo-Prawniczy Wojskowej Akademii Politycznej im. Feliksa Dzierżyńskiego. A. Lityński, O prawie i sądach początków Polski Ludowej, Białystok 1999, s. 165.

${ }^{14}$ Kluczowe znaczenie miał w tym kontekście nowy rozdział XVII (art. 85-103) dotyczący zbrodni stanu (przestępstw przeciwko państwu). Na 19 artykułów tego rozdziału, aż 10 przewidywało karę śmierci. Szczególnie złą sławę zyskał art. 86 KKWP, w którym przewidywano karę śmierci za „usiłowanie usunięcia przemocą ustanowionych organów władzy Narodu”. Przy czym przez usiłowanie rozumiano nawet demonstracje uliczne. Widoczna jest w tym przypadku recepcja sowieckich wzorców na grunt polskiego porządku prawnego, a mianowicie penalizowanie zachowania dalekiego od skutku przestępczego, a więc usiłowania i przygotowania. Sam zamiar sprawstwa wystarczył za podstawę do orzeczenia kary śmieci. Kara śmierci groziła także za „przejście na stronę nieprzyjaciela”, „działanie na korzyść nieprzyjaciela”, „,żenie, znieważanie lub wyszydzanie ustroju państwa”, „nawoływanie do zakładania lub przystępowania do organizacji faszystowskich”, a nawet za „nawoływanie do czynów skierowanych przeciwko jedności sojuszniczej”. Tak ogólnikowo sformułowane kwalifikacje prawne powodowały, że właściwie każde zachowanie można było zinterpretować jako przestępcze. Ibidem, s. 72-73. 
gany prowadzące śledztwo lub dochodzenie wyłączyć i sam przeprowadzić określone czynności. Tendencje do odcinania się od przedwojennego wojskowego prawa karnego widoczne były także na płaszczyźnie symbolicznej, gdyż wyrokowanie miało być wykonywane nie w imieniu państwa polskiego, ale narodu polskiego ${ }^{15}$. Najważniejszą zmianą wprowadzoną przez wyżej wspomniany dekret było przekazanie do właściwości sądów wojskowych spraw osób cywilnych oskarżonych o zbrodnie stanu (przestępstwa przeciwko państwu). W tym kontekście należy wspomnieć o wojskowych sądach rejonowych (WSR), najbardziej represyjnych organach sądownictwa tamtego okresu, które wyjątkowo krwawo zapisały się w historii komunistycznej Polski. Utworzone zostały 20 stycznia $1946 \mathrm{r}$. na mocy rozkazu Naczelnego Dowódcy Wojska Polskiego i Ministra Obrony Narodowej, marszałka „Roli” Żymierskiego (marszałek Rokossowski obejmie ten urząd dopiero w 1949 r.). Wojskowe sądy rejonowe były de facto sądami specjalnymi, gdyż funkcjonowały poza strukturą sądownictwa wojskowego, bezpośrednio podlegając Najwyższemu Sądowi Wojskowemu (NSW). Miały funkcjonować na wzór trybunałów wojennych NKWD orzekających w sprawach o przestępstwa kontrrewolucyjne. Wojskowe sądy rejonowe były właściwie organami nielegalnymi, powołanymi bez żadnej podstawy prawnej, gdyż utworzono je „dla danego województwa”, a nie „przy jednostkach wojskowych, jako sądy wojskowe tych jednostek". Było to więc pogwałcenie art. $17^{16}$ wspomnianego dekretu PKWN z dnia 23 września 1944 r. Zważywszy na to, wyroki wydane przez te sądy należy uznać nie tyle za nieważne, co nieistniejące. Zadaniem WSR, jak napisał wprost w 1946 r. oficer Armii Czerwonej, absolwent Wyższych Wojskowych Kursów Prawniczych w Moskwie oraz prezes NSW płk Aleksander Michniewicz, była „eliminacja i eksterminacja wrogów Narodu” ${ }^{17}$. Wojskowe sądy rejonowe w latach 1946-1955 wydały kilka tysięcy wyroków śmierci.

Innym wyrazem wypaczenia i degeneracji sądownictwa początków Polski Ludowej były tzw. sądy tajne (sekcje tajne) istniejące w latach 1950-1954 w Warszawie. Pomysł ich powstania narodził się w Ministerstwie Bezpieczeństwa Publicznego (MBP) w porozumieniu z kierownictwem PZPR i rządu. Celem nowej instytucji było „rozpoznawanie spraw karnych politycznych o wielkiej wadze dla interesów Partii i Państwa”. Sama liczba spraw miała być względnie niewielka, a rozpatrywane być miały przez oddanych władzy sędziów, z udziałem zaufanych

15 Ibidem, s. 76.

${ }^{16}$ Art. 17: „Naczelny Dowódca określa przy jakich jednostkach (formacjach) wojskowych poza armiami, okręgami, admiralicjami, korpusami i dywizjami tworzy się wojskowe sądy danych jednostek". Dz.U. z 1944 r. nr 6 poz. 29.

${ }_{17}$ M. Zaborski, Ustrój sądów wojskowych $w$ Polsce $w$ latach 1944-1955, Lublin 2005, s. $222-225$. 
obrońców, przy całkowitym wyłączeniu jawności ${ }^{18}$. Formalnie rzecz ujmując sądem tajnym była komórka Sądu Apelacyjnego dla m.st. Warszawy (od 1 stycznia 1951 r. Sądu Wojewódzkiego). Jej oficjalna nazwa to Sekcja III Wydziału IV Sądu Apelacyjnego/Wojewódzkiego. Organem rewizyjnym (odwoławczym) była tajna komórka Sądu Najwyższego (Sekcja III SN, następnie przemianowana na Sekcję $\mathrm{X}$ do spraw szczególnych). W jej składzie zasiadali m.in. sędziowie Emil Merz, Gustaw Auscaler oraz Igor Andrejew, późniejszy autor podręcznika „Prawo karne Polski Ludowej" z 1954 r. i współautor projektu kodeksu karnego z 1969 r. Sekcje tajne formalnie funkcjonowały w strukturze sądownictwa powszechnego, ale w praktyce były organami samodzielnymi. Rozpatrywały sprawy napływające z całej Polski, co odbywało się z pogwałceniem ówczesnych przepisów o właściwości sądów. Rozprawy zaś początkowo (do połowy 1952 r.) odbywały się w celach więzienia mokotowskiego nr 1 na ul. Rakowieckiej w Warszawie, gdzie oskarżony pozbawiony był właściwie wszelkich praw i gwarancji procesowych, co stanowiło najdalej idący przejaw stalinowskiego bezprawia. To właśnie ofiarą sekcji tajnych padł major Bolesław Kontrym, ps. „Żmudzin”.

Nie jest moją intencją szczegółowe zreferowanie życiorysu Bolesława Kontryma, gdyż ten życiorys ma już swoją literaturę. Nie sposób jednak zrozumieć zarzutów zawartych w akcie oskarżenia, jak i treści samego wyroku oraz jego uzasadnienia bez przypomnienia pewnych faktów. Ograniczę się zatem do przybliżenia tych wydarzeń z życia majora, które będą mieć istotne znaczenie dla organów bezpieczeństwa, jak i wymiaru sprawiedliwości Polski Ludowej, i które przesądzą o jego tragicznym losie, zwłaszcza tych okoliczności faktycznych, które przez stalinowski sąd zostaną uznane za obciążające. Pozwoli to na lepsze zrozumienie stosunku i polityki rozrachunku komunistów wobec funkcjonariuszy państwowych przedwojennej Polski, rozliczania ich ze służby w organach państwowych II RP i działalności konspiracyjnej z czasów okupacji, zgodnie z przyjętą przez „władzę ludową” wykładnią i jej rozumieniem pojęć takich, jak: ,interes państwa”, „zdrada narodu”, czy „działanie na korzyść ruchu faszystowskiego”.

Pozostając w ramach tematycznych niniejszego artykułu, przypomnienie życiorysu Bolesława Kontryma (ur. 1898 r.) należałoby rozpocząć od 1919 r., w którym został on aresztowany przez bolszewików i przymusowo wcielony do Armii Czerwonej. W służbie tej wykazał się takim męstwem i zdolnościami dowódczymi, że w 1921 r. zakończył ją awansem do rangi kombryga (dowódcy brygady), zdobyciem aż trzykrotnie Orderu Czerwonego Sztandaru oraz otrzymaniem przydziału na studia do Akademii Sztabu Generalnego w Moskwie. W 1922 r. Kontrym w zamian za uzyskanie możliwości powrotu do Polski wraz z rodziną,

${ }^{18}$ K.M. Piekarska, Naruszenie zasady jawności w ,, sądach tajnych”, [w:] G. Rejman (red.), Prawo karne w okresie stalinizmu, Warszawa 1995, s. 31. 
nawiązał współpracę z płk. Romualdem Wolikowskim, attaché wojskowym przy poselstwie RP w Moskwie i podjął się działalności szpiegowskiej, przekazując mu regularnie liczne informacje o charakterze wywiadowczym (dane dotyczące organizacji, programu nauczania i personelu Akademii oraz dyslokacji sowieckich jednostek wojskowych, także szkice map strategicznych etc.). Działalność wywiadowcza Kontryma nie trwała jednak długo. Już w połowie 1922 r. pojawiło się realne zagrożenie dekonspiracji przez sowiecki kontrwywiad, wskutek czego - po uprzednim przerzuceniu swej rodziny do Polski - Kontrym z pomocą polskich placówek dyplomatycznych i konsularnych, przekroczył nielegalnie granicę polsko-sowiecką ${ }^{19}$. W Polsce w zamian za owocną współpracę z wywiadem RP, Kontrym został skierowany do służby w Straży Granicznej, a po jej likwidacji w 1923 r. automatycznie przeszedł do Granicznej Policji Państwowej, która przejęła zadania Straży Granicznej. W formacjach policyjnych II RP Kontrym służyć będzie aż do wybuchu drugiej wojny światowej, przez cały ten czas na kresach wschodnich ${ }^{20}$.

Służba Bolesława Kontryma w Policji zasługuje na bardziej szczegółowe omówienie, gdyż to właśnie działalność w formacjach policyjnych II RP będzie podstawą późniejszego aktu oskarżenia. W 1924 r. nastąpiła kolejna reorganizacja formacji strzegących granic RP i w miejsce Policji Granicznej utworzono Korpus Ochrony Pogranicza (KOP) odpowiedzialny za ochronę wschodniej granicy, tj. za zwalczanie działalności terrorystyczno-dywersyjnej podejmowanej przez bojowników i agentów wysyłanych na terytorium Polski przez ZSRR. Kontrym nie przeszedł do KOP, gdyż zdecydował się na rozpoczęcie służby w Policji Politycznej, specjalnym pionie Policji Państwowej (PP), zajmującym się zwalczaniem przestępczości antypaństwowej, głównie rozpracowywaniem komunistycznych ugrupowań, ale też organizacji radykalnie prawicowych. Służąc w tej specjalnej formacji Kontrym, jako aspirant, został w 1925 r. kierownikiem Ekspozytury Okręgowego Urzędu Śledczego Policji Politycznej w Baranowiczach. Na tym stanowisku przy pomocy sieci policyjnych agentów zajmował się zwalczaniem organizacji komunistycznych będących de facto sowieckimi ekspozyturami, doprowadzając m.in. do licznych aresztowań i likwidacji Komitetu Miejskiego Komunistycznej Partii Zachodniej Białorusi (KPZB) w Baranowiczach i Komitetu Rejonowego KPZB w Mołczadzi. Za te zasługi w 1926 r. został skierowany na kurs do Szkoły Oficerów Policji Państwowej w Warszawie i po jego ukończeniu, już w randze podkomisarza, objął w Słonimie stanowisko zastępcy komendanta

${ }^{19}$ H. Sikorska, Człowiek Nieustraszony, „Biuletyn Informacyjny” 2001, rok XI, nr 2 (130), s. 10.

${ }^{20}$ Z. Cydzikowa, I. Makowska, Dla uczczenia pamięci naszego dowódcy mjr. Bolesława Kontryma „Żmudzina”, , Białego”, Warszawa 1995, s. 1. 
powiatowej PP. W tym okresie Kontrym kierował m.in. akcją zatrzymania wysokiego funkcjonariusza KC KPZB Jakuba Wołpiańskiego, u którego znaleziono sprawozdanie ze stanu osobowego partii. Materiały te oraz informacje ujawnione przez zatrzymanego, który zdecydował się na współpracę z policją, doprowadziły do aresztowania licznych aktywistów komunistycznych na terenie Wołkowyska, Białegostoku i Brześcia. Latem 1928 r. Kontrym objął stanowisko komendanta powiatowej PP w Szczuczynie, a w 1931 r. w Nowogródku, który był rejonem wzmożonej aktywności komunistów skupiających się wokół działalności antypodatkowej (wzywania do niepłacenia podatków). Obejmując w 1933 r. stanowisko komendanta powiatowej PP w Brześciu, Kontrym przyczynił się do aresztowania kilkudziesięciu członków Komunistycznej Partii Zachodniej Ukrainy (KPZU) ${ }^{21}$.

Największe sukcesy w walce $\mathrm{z}$ ruchem komunistycznym Kontrym odniósł w Białymstoku, w którym w 1936 r., już jako komisarz, został kierownikiem Wydziału Śledczego Komendy Wojewódzkiej PP. Białystok w latach trzydziestych uchodził wręcz za bastion komunizmu i radykalnej lewicy, co było pokłosiem błyskawicznej industrializacji, trudności ekonomicznych i bardzo wysokiej stopy bezrobocia wśród robotników. Sympatiom prokomunistycznym sprzyjał również fakt, że na wpływy sowieckie bardzo podatne były najuboższe warstwy mniejszości żydowskiej, która - według spisu ludności z 1931 r. - stanowiła aż 42\% ogółu mieszkańców miasta. Komuniści skutecznie też infiltrowali słabe w tym mieście struktury policyjne. Z tego okresu Kontryma najbardziej obciążą późniejsze zeznania Walentyny Najdus, aresztowanej działaczki komunistycznej stojącej na czele Komitetu Miejskiego KPZB w Białymstoku. Wspominała ona, że zarówno wobec niej, jak i pozostałych aresztowanych aktywistów KPZB stosowano w białostockim więzieniu rozmaite tortury ${ }^{22}$. Dodała przy tym, że niedozwolone metody śledcze praktykowane były jedynie w Białymstoku, a niechlubnym reprezentantem tego bezprawnego systemu rzekomo miał być właśnie Kontrym ${ }^{23}$. Ostatnie

21 Z. Uniszewski, Biografia policyjna i żotnierska niewinnie straconego mjr. Bolestawa Kontryma ,Żmudzina” (1898-1953), „Przegląd Historyczno-Wojskowy” 2001, r. II (LIII), nr 3 (188), s. $18-20$.

${ }^{22}$ Wydaje się, że zeznania Walentyny Najdus mogą być w pewnym stopniu prawdziwe. Podobne zeznania składali inni komuniści polscy aresztowani w okresie przedwojennym, zwłaszcza na terenach wschodnich. Te same zarzuty stawiane były m.in. funkcjonariuszom Urzędu Śledczego w Łucku przez działaczy KPZU sądzonych w słynnym procesie łuckim w 1934 r. Jednakże Najdus nie zeznała, jakoby Kontrym znęcał się nad nią osobiście.

${ }^{23}$ Po wojnie w czasie śledztwa przeciwko Kontrymowi, Walentyna Najdus zeznała, że: „po zatrzymaniu przyprowadzono mnie do gmachu „defy” - policji politycznej w Białymstoku przy ulicy Warszawskiej. Po przyprowadzeniu mnie do gmachu chcieli przeprowadzić u mnie rewizję osobistą mężczyźni, na co ja się nie zgodziłam. W związku z tym przeprowadzono w stosunku do mnie szykany, w ten sposób, że nie wypuszczano mnie nawet do ubikacji. W ciągu dalszego śledztwa, gdy nie przyznawałam się do przynależności partyjnej, byłam bita po twarzy i po całym ciele. Kopano mnie, targano za włosy i kazano pełzać do butów i przy tym mówiono: ,jeszcze będziesz nam buty 
lata istnienia przedwojennej Polski Kontrym przepracował na stanowisku kierownika Wydziału Śledczego KW PP w Wilnie, kolejnym mieście, w którym wpływy komunistów były znaczne, i tam zastał go wybuch drugiej wojny światowej.

Dla celów niniejszego artykułu zasadne jest ograniczenie opisu okupacyjnych losów majora Kontryma do tych epizodów działalności podziemnej, które staną się przedmiotem zainteresowania rządzących po wojnie komunistów. W tym kontekście znaczenie będzie mieć przydział Kontryma do organizacji „Wachlarz” w 1942 r. „Wachlarz” był specjalną komórką AK zajmującą się działalnością dywersyjną (wysadzaniem mostów i torów kolejowych) na liniach zaopatrzeniowych Wehrmachtu walczącego na froncie wschodnim. Rok później Kontrym na krótko został mianowany szefem Kierownictwa Dywersji (Kedywu) Okręgu Brześć AK. Najważniejszym jednak epizodem z czasów wojny było oddelegowanie Kontryma przez Delegata Rządu RP na Kraj do Państwowego Korpusu Bezpieczeństwa (PKB), podziemnej policji, mającej za zadanie zwalczanie pospolitej przestępczości i przygotowywanie kadr mających - wedle zamierzeń rządu na uchodźstwie - zastąpić w przyszłości tzw. policję granatową. Kontrym został w tej organizacji szefem Centralnej Służby Śledczej i zastępcą komendanta PKB. W praktyce działalność PKB koncentrowała się na likwidacji konfidentów i współpracowników gestapo oraz NKWD, co czynił sam Kontrym, stojący na czele Ekspozytury Urzędu Śledczego PKB dla m.st. Warszawy, kryptonim „Start”. Jednocześnie od 1943 r. dowodził on specjalnym oddziałem „Sztafeta-Podkowa” ochraniającej lokale konspiracyjne Delegatury Rządu RP na Kraj. Koniec wojny spędził Kontrym na Zachodzie na służbie w słynnej 1. Dywizji Pancernej generała Maczka. To właśnie tęsknota za ojczyzną i pragnienie powrotu do Polski zaważą na losie Kontryma ${ }^{24}$.

Możliwość powrotu pojawiła się, gdy niespodziewanie odnalazł się starszy brat Kontryma, Konstanty, który od 1923 r. przebywał w ZSRR i z którym rodzina od tamtego czasu straciła kontakt. Okazało się, że Konstanty nie tylko przeżył, ale dosłużył stopnia generała w Ludowym Wojsku Polskim. Nakłonił on swego młodszego brata do powrotu do Polski, udzielając gwarancji bezpieczeństwa z powołaniem się na osobiste rozmowy z marszałkiem Żymierskim, Radkiewiczem i innymi czołowymi przedstawicielami władzy komunistycznej. Bolesław Kontrym powrócił do Polski w dniu 15 maja 1947 r. Początkowo znalazł zatrudnienie w Ministerstwie Aprowizacji, przeszedł także pozytywną weryfikację przed Komisją Rehabilitacyj-

lizać". Gdy tego nie robiłam, obijano mnie po kątach i dawano szturchańce. Byłam do tego stopnia stłuczona, że całe ciało miałam pokryte sińcami. W taki sam sposób bito i maltretowano przy badaniach pozostałych członków KPZB aresztowanych wraz ze mną w Białymstoku, a nawet w stosunku do niektórych stosowano gorsze metody maltretowania". Protokół przesłuchania świadka Najdus Walentyna z 4 października 1951 r. W. Pasek, Bolesława Kontryma życie zuchwałe. Biografia żotnierza i policjanta 1898-1953, Warszawa: Fronda 2006, s. 86-90.

${ }^{24}$ Ibidem, s. $118-141$. 
no-Kwalifikacyjną dla byłych funkcjonariuszy PP przy Prezydium Rady Ministrów, która 27 września tego samego roku wydała mu zaświadczenie o braku zastrzeżeń odnośnie zatrudnienia w służbie państwowej. Następnie został zatrudniony na stanowisku naczelnika Wydziału Ogólnego w Centralnym Zarządzie Państwowego Przemysłu Fermentacyjnego w Warszawie i na tym stanowisku pozostał aż do aresztowania. Przez cały ten czas nie mógł wiedzieć, że już dokładnie na dwa miesiące przed swoim powrotem, 15 marca $1947 \mathrm{r}$. założono mu teczkę osobową w Głównym Zarządzie Informacji Wojska Polskiego (GZI), na polecenie samego szefa GZI, sowieckiego oficera, płk. Dymitra Wozniesienskiego ${ }^{25}$.

Bolesław Kontrym został aresztowany najprawdopodobniej 30 października 1948 r., jako podejrzany o naruszenie art. 7 dekretu z 13 czerwca 1946 r. o przestępstwach szczególnie niebezpiecznych w okresie odbudowy państwa, zwanego potocznie małym kodeksem karnym ${ }^{26}$. Wątpliwość co do dnia aresztowania wynika ze sprzeczności dat figurujących na różnych dokumentach ${ }^{27}$. Początkowo nie było też wiadomo, gdzie Kontrym przebywał aż do dnia 5 sierpnia 1949 r., gdyż dopiero ta data określa przyjęcie więźnia na stan więzienia mokotowskiego. Obecnie dysponujemy już wiedzą, że przebywał on w tajnej willi-areszcie MBP (kryptonim „Spacer”) w Miedzeszynie pod Warszawą, a więc w tym samym miejscu, w którym osadzony zostanie Władysław Gomułka w $1951 \mathrm{r}$. W areszcie tym, bezpośrednio podlegającym Departamentowi X MBP, panował bezwzględny terror, którego ofiarą padł również Kontrym. Brutalne śledztwo, oparte głównie na biciu gumowymi pałkami, prowadzone od października 1948 r. do lutego 1949 r., doprowadziło do gangreny nogi, wobec czego przeniesiono Kontryma do szpitala więzienia mokotowskiego, w którym przebywał aż do dnia 5 sierpnia 1949 r. Po zażegnaniu groźby amputacji nogi, śledztwo wznowiono i trwało ono aż do dnia 5 grudnia 1951 r., a więc ponad 3 lata $^{28}$. Okres śledztwa - nawet przy uwzględnie-

${ }^{25}$ Ibidem, s. 240-153.

${ }^{26}$ Art. 7: „Kto, działając na szkodę Państwa Polskiego, gromadzi lub przekazuje wiadomości, dokumenty lub inne przedmioty stanowiące tajemnicę państwową lub wojskową, podlega karze więzienia na czas nie krótszy od lat 5 lub dożywotnio albo karze śmierci”. Dz.U. 1946 nr 30 poz. 192.

${ }^{27}$ Większość autorów zajmujących się biografią Kontryma przytacza datę 13 października jako dzień aresztowania. Ta sama data występuje też na większości dokumentów (np. w postanowieniu o tymczasowym aresztowaniu z dnia 15 października 1948 r., czy w kwestionariuszu personalnym w aktach sprawy 563/49. Jednakże sam Kontrym w pismach swych kierowanych do sądu powołuje się na datę 30 października (np. pismo do Sądu Wojewódzkiego w Warszawie dotyczące możliwości widzenia się z synem). Tę samą datę jako datę zatrzymania przytacza żona Kontryma, Wanda Kontrym, w pismach kierowanych do sądu i prokuratury.

${ }_{28}$ Tadeusz Nowiński, przebywający w jeden celi z Kontrymem w okresie 1950-1952, wspomina, że znęcano się nad Kontrymem w sposób wyjątkowo okrutny. Kontrymowi wybito osiem zębów, miażdżono palce u stóp, bito gumowymi pałkami i metalowym prętem. Stosowano wobec niego konwejer przez ponad 3 tygodnie, pozbawiając go snu, jedzenia i wody. Przesłuchania te prowadził i nadzorował oficer śledczy, kpt. Józef Dusza, jeden z najbrutalniejszych funkcjonariuszy UB. Na 
niu standardów czasów stalinowskiej Polski - należy uznać za wyjątkowo długi ${ }^{29}$. W tym kontekście można nadmienić, że Bolesławem Kontrymem interesowały się dwa czołowe organy bezpieczeństwa Polski Ludowej i być może tym należy tłumaczyć długość jego trwania. Funkcjonariusze MBP koncentrowali się na kwestii zwalczania przez Kontryma organizacji i aktywistów komunistycznych przed wojną oraz w czasie okupacji niemieckiej, zaś GZI (kontrwywiad wojskowy) skupiał swą uwagę wokół działalności wywiadowczej Kontryma prowadzonej w 1922 r. oraz jego dezercji z Armii Czerwonej, ucieczki do Polski i ewentualnych związkach z bratem, generałem LWP ${ }^{30}$.

Aktem oskarżenia, sporządzonym dnia 14 lutego 1952 r. przez oficera śledczego MBP por. Adama Adamuszka i zatwierdzonym przez Dyrektora Departamentu X MBP płk. Anatola Fejgina, zarzucono Kontrymowi w punkcie pierwszym, iż „W okresie od 1925 do września 1939 r. na terenie województw nowogrodzkiego, brzeskiego, lubelskiego, białostockiego i wileńskiego, idąc na rękę ruchowi faszystowskiemu, działał w zakresie rozstrzygania w sprawach publicznych na szkodę Narodu Polskiego, przyczyniając się do rozbicia rewolucyjnego ruchu robotniczego i dręczenia działaczy komunistycznych, przebywających w aresztach lub więzieniach z powodu ich działalności politycznej przez to, że jako kierownik ekspozytury Policji Politycznej w Baranowiczach, a następnie zastępca komendanta powiatowego w Słonimie, komendant powiatowy w Szczuczynie, Nowogródku, Brześciu, zastępca naczelnika Urzędu Śledczego w Białymstoku i Wilnie, kierował pracami podległych mu jednostek policyjnych, którym wydawał polecenia i wytyczne w kierunku rozpracowywania organizacji komunistycznych, posiadał $\mathrm{w}$ tych organizacjach prowokatorów i agentów, z którymi osobiście utrzymywał kontakty i odbierał od nich meldunki z przeprowadzonych rozpracowań komunistycznych oraz udzielał im wskazówek do dalszej pracy po tej linii, w wyniku czego zostały zlikwidowane między innymi Komitet Miejski Komunistycznej Partii Zachodniej Białorusi (KPZB) w Baranowiczach, Komitet w Kościniewie-Żyrowicach pod Słonimem, Komitety Rejonowe Komunistycznej Partii Zachodniej Ukrainy (KPZU) w Kamienicy Żyrowickiej, Małorycie, Domaczewie, Mokranach, Czernawczycach, Kamieńcu Litewskim i Wysoko-Litewskim w powiecie brzeskim, trzy kolejne Komitety Miejskie KPZB w Białymstoku oraz aresztowani działacze Walentyna Najdus, Kapłan Żenia, Malarewicz Lila, jej mąż i Piotr Słucki oraz inni, przeciwko którym prowadził on osobiście dochodzenia, wymuszając od nich zeznania przy użyciu siły fizycznej, a następnie występując jako świadek dowodowy na rozprawach przeciwko nim, spowodował, że większość z nich została skazana na długoletnie więzienie"31.

skutek tych tortur Kontrym zachorował na ropne zapalenie płuc i trzykrotnie znalazł się w więziennym szpitalu, przebywając w nim łącznie ponad 7 miesięcy. Z. Uniszewski, op.cit., s. 35.

29 W. Pasek, op.cit, s. 260-288.

${ }^{30}$ Ibidem, s. 251.

31 Akt oskarżenia przeciwko Bolesławowi Kontrymowi, sygn. akt IPN GK 317/812, s. 2-3. 
Punkt drugi oskarżenia dotyczył działalności Kontryma z okresu okupacji niemieckiej. „Żmudzin” został oskarżony o to, że „w okresie od września 1942 do sierpnia 1944 r. idąc na rękę władzy hitlerowskiego państwa niemieckiego, działał na szkodę Narodu Polskiego przez to, że jako Komendant III Odcinka organizacji dywersyjnej »Wachlarz«, działającej na terenach ziem wschodnich, zorganizował specjalne oddziały, które prowadziły czynną walkę z ugrupowaniami lewicowymi i oddziałami partyzantki radzieckiej, prowadzącymi tam dywersję i akcje sabotażowe przeciwko okupantowi [...]. A po objęciu na początku 1943 r. stanowiska szefa Centrali Służby Śledczej w głównym Inspektoracie Państwowego Korpusu Bezpieczeństwa (PKB), mającego na celu zahamowanie ruchu narodowo-wyzwoleńczego i fizyczne wyniszczenie członków organizacji lewicowych, brał czynny udział w zwalczaniu działalności antyfaszystowskiego ruchu na terenie całego kraju, a także w rozpracowywaniu członków PPR, GL-AL [...]"32. Ponadto oskarżono Kontryma o to, że wydawał on podległym sobie jednostkom organizacyjnym polecenia nawiązania kontaktu i współpracy z niemieckimi władzami bezpieczeństwa na odcinku zwalczania lewicy. Uzasadnienie aktu oskarżenia przekonywało, że Policja Polityczna, której funkcjonariuszem był Kontrym, stanowiła główną instytucję zwalczającą ruch komunistyczny w przedwojennej Polsce. z Komunistyczną Partią Polski na czele. Działalność ta w uzasadnieniu aktu oskarżenia została określona mianem polityki antynarodowej i zdradzieckiej, kontynuowanej podczas okupacji niemieckiej pod dyktando anglosaskich mocodawców i realizowanej we współpracy z okupantem niemieckim ${ }^{33}$. Czyny opisane w punkcie pierwszym aktu oskarżenia stanowiły przestępstwa uregulowane w art. 3 w zw. z art. 5 ust. 2 dekretu z dnia 22 stycznia 1946 r. o odpowiedzialności za klęskę wrześniową i faszyzację życia państwowego ${ }^{34}$, zaś czyny z punktu dru-

32 Ibidem, s. 4-5.

${ }^{33}$ Ibidem, s. 7.

${ }^{34}$ Art. 3: „Kto, idąc na rękę ruchowi faszystowskiemu lub narodowo-socjalistycznemu, działał w zakresie rozstrzygania w sprawach publicznych na szkodę Narodu lub Państwa Polskiego w sposób inny niż przewidziany w art. 1 lub 2, podlega karze więzienia”. Art. 5 ust. 1: „Kto brał udział w dręczeniu osoby przebywającej lub osadzonej w miejscu odosobnienia, obozie, areszcie lub zakładzie karnym z powodu jej działalności politycznej lub społecznej, podlega karze więzienia". Ust. 2 tegoż artykułu przewidywał karę więzienia dla tego, kto przyczynił się lub spowodował przestępstwo opisane w ust. 1. Dz.U. 1946 nr 5 poz. 46. Warto jednak nieco więcej uwagi poświęcić omawianemu dekretowi. Spośród wszystkich tzw. dekretów odwetowych, dekret o odpowiedzialności za klęskę wrześniową i faszyzację życia państwowego miał najbardziej rozrachunkowy charakter względem funkcjonariuszy II RP. Stanowił też wyraz złamania zasady „lex retro non agit”, gdyż odnosił się do czynów popełnionych od 22 stycznia 1921 r. do 31 sierpnia 1939 r. Formalnie był wymierzony w osoby sprawujące ,naczelne funkcje kierownicze” w państwie, ale w praktyce na jego podstawie możliwe było osądzenie i skazanie każdego urzędnika lub oficera II RP. W uzasadnieniu projektu dekretu przekonywano, że winę za klęskę Polski w wojnie z Niemcami ponosi obóz sanacji, który był odpowiedziany za ustanawianie faszystowskich zasad w państwie polskim i tym samym wzmacniał on ruch faszystowski w całej Europie, działając przy tym na szkodę Na- 
giego aktu oskarżenia wyczerpywały znamiona przestępstwa opisanego w art. 1 pkt. b „sierpniówki” "35, a więc dekretu PKWN o wymiarze kary dla faszystowsko-hitlerowskich zbrodniarzy oraz dla zdrajców Narodu Polskiego.

rodu Polskiego. A. Lityński, op.cit., s. 111-112. Dekret ten był też wyrazem pewnej ogólnej linii politycznej przyjętej przez ZSRR, a realizowanej po wojnie rękami polskich komunistów, zgodnie z którą władza w Polsce po 1926 r. była władzą nielegalną, uzurpatorską i faszystowską, tak samo jak organy podporządkowane w czasie wojny rządowi londyńskiemu. Chodziło tu więc o zerwanie ciągłości państwowej, uznanie bezprawności całego systemu państwowego II RP, który rzekomo działał w interesie państw faszystowskich lub państwa narodowosocjalistycznego np. poprzez zwalczanie ruchu komunistycznego, zarówno przed wojną, jak i w jej trakcie. Naturalną konsekwencją tego poglądu jest postawienie poza prawem każdej osoby, która działała w interesie II RP. W ujęciu tej wykładni polski rząd na uchodźstwie, jak i Polskie Państwo Podziemne oraz AK właściwie nie miały podmiotowego prawa do walki z okupantem niemieckim, gdyż kontynuowały profaszystowskie działania II RP, zatem były sprzeczne z celami i planami ZSRR wobec Polski. Działania prowadzone przez podporządkowane rządowi londyńskiemu ośrodki w tej optyce uznawano nie za walkę z okupantem niemieckim, ale za wyraz przestępczego wspierania faszyzmu. G. Rejman, Prawo karne w latach 1944-1956, [w:] G. Rejman (red.), Prawo okresu stalinowskiego. Zagadnienia wybrane, Warszawa 1992, s. 44-47. Ta wrogość Sowietów do przedwojennego państwa polskiego oraz jego wojennej ciągłości w postaci wspomnianych wyżej ośrodków wynikała z kilku zasadniczych powodów. Po pierwsze, nie ulega wątpliwości, że antykomunizm był jednym z fundamentów tożsamości kulturowej i politycznej odrodzonej RP. Przejawiał się on w postawach całej klasy politycznej i elit (stąd też wynikało marginalne znaczenie KPP), miał także swą intelektualną podbudowę w literaturze i publicystyce polskiej okresu międzywojennego. Postawy antykomunistyczne umocniły się po zwycięstwie Polski w wojnie z bolszewikami w 1920 r. J. Kloczkowski, F. Musiał, Antykomunizm - racja stanu II RP, [w:] J. Kloczkowski, F. Musiał (red.), W obronie niepodległości. Antykomunizm w II Rzeczypospolitej, Kraków 2009, s. 9. Patrząc zaś z perspektywy ZSRR, Polska była najsilniejszym militarnie państwem mającym wspólną granicę z Sowietami i w związku tym Polskę postrzegano jako głównego potencjalnego agresora, z terytorium którego miałby nastąpić atak sił imperialistyczno-kapitalistycznych. Tym przeświadczeniem należy tłumaczyć także niezwykle agresywną antypolską propagandę sowiecką, która tak głęboko zakorzeniła się w świadomości sowieckiego społeczeństwa, że z faszyzmem w pierwszej kolejności kojarzono Polskę, a dopiero potem Włochy Mussoliniego czy III Rzeszę. N. Iwanow, Zapomniane ludobójstwo. Polacy w państwie Stalina „Operacja polska” 1937-1938, Kraków 2014, s. 118-119. Kluczem do zrozumienia takiego stanowiska Moskwy jest fakt, że, jak pisał R. Pipes, bolszewicy terminem „faszystowski” posługiwali się w odniesieniu nie tylko do opisu ruchów antykomunistycznych, co po prostu niekomunistycznych. Wprawdzie dopiero w 1933 r. Komintern określił faszyzm mianem ,jawnej, terrorystycznej dyktatury najbardziej reakcyjnych, szowinistycznych i imperialistycznych elementów kapitalizmu finansowego", ale już na V Kongresie Kominternu w 1924 r. postanowiono uznać ruchy socjalistyczne i ludowe za „lewicę faszystowską” (stanowisko to złagodzono dopiero na VII Kongresie Międzynarodówki Komunistycznej w 1935 r., aby uzasadnić nową koncepcję zawierania sojuszy z ugrupowaniami socjalistycznymi i ludowymi w ramach budowy jednolitych i demokratycznych frontów ludowych). Znane są słowa Stalina, że „obiektywnie socjaldemokracja to umiarkowane skrzydło faszyzmu”. R. Pipes, Rosja bolszewików, Warszawa 2013, s. 245.

${ }^{35}$ Art. 1 pkt. b: „Kto, działając na rękę władzy okupacyjnej niemieckiej działał lub działa na szkodę osób przebywających na obszarze Państwa Polskiego, w szczególności przez ujęcie lub wywożenie osób poszukiwanych albo prześladowanych przez władzę okupacyjną z jakichkolwiek 
Obrońcą „Żmudzina” został wyznaczony z urzędu adwokat Mieczysław Maślanko, zapewne najsłynniejszy obrońca w procesach sądowych okresu stalinizmu w Polsce. Maślanko występował w licznych procesach karnych czołowych przedstawicieli środowiska niepodległościowego, działając jako obrońca m.in. prezesa I Zarządu Głównego Wolności i Niezawisłości (WiN) Jana Rzepeckiego, prezesa II Zarządu Głównego WiN Franciszka Niepokólczyckiego, rotmistrza Witolda Pileckiego, Zygmunta Szendzielarza „Lupaszki”, przedwojennego działacza endeckiego Adama Doboszyńskiego, Kazimierza Moczarskiego oraz gen. „Nila” Fieldorfa, szefa Kedywu AK i najsłynniejszej ofiary sądów tajnych ${ }^{36}$. Maślanko, jako jeden z kilku obrońców, figurował na sporządzonej przez bezpiekę liście adwokatów mogących występować przed sądami tajnymi. Za oczywiste należy uznać, że byli to prawnicy wykazujący się pożądanymi przez władzę komunistyczną poglądami politycznymi i całkowitą dyspozycyjnością i z tych powodów działalność adwokata Maślanki, jak i jego procesową rolę obrońcy, należy brać w cudzysłów. Adwokat ten de facto występował jako pomocnik prokuratora, nie tylko nie podejmując żadnych kroków w celu zapewnienia rzetelnej i prawdziwej obrony swoich klientów, ale jawnie i wprost podzielając zasadnicze tezy oskarżenia. O jego nagannej postawie i stosunku do roli obrońcy Kontryma, jaka została mu wyznaczona, najdobitniej świadczy fakt, iż ze swoim klientem skontaktował się dopiero na dzień przed rozprawą główną, tj. 12 czerwca 1952 r., mimo że już 28 lutego tego roku Kontrym napisał podani ${ }^{37}$ do Sądu Wojewódzkiego w Warszawie, w którym wnosił o ustanowienie obrońcy z wyboru (prośba ta została odrzucona).

przyczyn (z wyłączeniem ścigania za dokonanie przestępstw pospolitych), podlega karze śmierci”. Dz.U. $1944 \mathrm{nr} 4$ poz. 16.

36 W. Pasek, op.cit., s. 312-313.

37 Pismo Bolesława Kontryma z dnia 28 lutego 1952 r. do Sądu Wojewódzkiego w Warszawie (sygn. akt IV K 60/52, III K 93/52 i IV K 157/57) w sprawie uzyskania możliwości skontaktowania się z rodziną oraz ustanowienia obrońcy z wyboru. Treść pisma: „w związku z doręczeniem mnie przez Sąd Wojewódzki w Warszawie aktu oskarżenia przestępstw przewidzianych w art. 3 i 5 Dekretu o faszyzacji kraju i art. 2 Dekretu o kolaboracji z niemieckimi władzami okupacyjnymi, wobec uniemożliwienia mnie skomunikowania się z rodziną w sprawie powołania do mej obrony adwokata z wyboru, zwracam się do Wysokiego Sądu z następującą prośbą:

1. proszę o zawiadomienie syna mojego Władysława Kontryma, wzgl. żony Wandy Kontrym zamieszkałej w chwili zaaresztowania mnie w Warszawie przy ul. Mazowieckiej $11 \mathrm{~m} 36$ o tym, że jestem oskarżony w powyższej sprawie, i że proszę o zaangażowanie do mej obrony adwokata z wyboru;

2. gdyby rodzina moja nie mogła zaangażować adwokata z wyboru, proszę Wysoki Sąd o wyznaczenie obrońcy z urzędu.

W obu wypadkach proszę usilnie Wysoki Sąd o umożliwienie mnie skomunikowania się z obrońcą jak najwcześniej przed rozprawą sądową, celem przekonsultowania merytorycznej strony sprawy, ustalenia miejsc zamieszkania szeregu świadków niezmiernie ważnych dla mojej obrony, zebrania dokumentów i informacji oraz złożenia Wysokiemu Sądowi odpowiednich wniosków”. 
Postępowanie karne w I instancji toczyło się przed wspomnianym wyżej sądem tajnym, tj. IV Wydziałem Karnym Sądu Wojewódzkiego dla m.st. Warszawy w składzie pod przewodnictwem sędziego Czesława Kosima z udziałem ławników - Stefana Łukowskiego i Stanisława Galicza oraz w obecności oskarżyciela, wiceprokuratora Generalnej Prokuratury Beniamina Wajsblecha. Pierwsza rozprawa miała miejsce 13 czerwca 1952 r., ale nie odbyła się w budynku sądu, ale na terenie więzienia mokotowskiego, co miało zapewnić warunki całkowitego wyłączenia jawności procesu, zwanego - w takich przypadkach - kiblowym. Wymowne jest także to, że ze wszystkich 22 osób wezwanych na rozprawę w charakterze świadków, tylko jedna - wspomniana wyżej przedwojenna komunistka Walentyna Najdus - przebywała na wolności. Pozostali osadzeni byli w więzieniu. Z treści wyjaśnień oskarżonego Kontryma wyłania się zarys linii obrony, zgodnie z którą przyznaje się on do służby w Policji Państwowej oraz do rozpracowywania struktur i działaczy komunistycznych w okresie przedwojennym, ale odrzuca zarzuty zawarte $\mathrm{w}$ drugim punkcie aktu oskarżenia (likwidacja członków ośrodków komunistycznych oraz współpraca z okupantem niemieckim). Przyjęta linia obrony, podtrzymywana zresztą do końca przewodu sądowego, wydaje się być - moim zdaniem - najrozsądniejszą z możliwych, bowiem fakt służby w PP wobec ogromu i dostępności dowodów (np. akta policyjne i sądowe) był niemożliwy do zatajenia, o czym Kontrym zapewne doskonale wiedział. Poza tym za przestępstwo to dekret o faszyzacji nie przewidywał kary śmierci, a co najwyżej - karę dożywotniego pozbawienia wolności. Karą śmierci było natomiast zagrożenie przestępstwo współpracy z okupantem niemieckim uregulowane w „sierpniówce”. Kontrym zapewne miał świadomość, że zostanie skazany, ale przyznanie się jedynie do popełnienia czynów objętych punktem pierwszym aktu oskarżenia rodziło szansę na zachowanie życia. Rozprawę przeprowadzono także w dniach 14, 16 i 23 czerwca 1952 r. Za każdym razem odbywała się ona na terenie więzienia mokotowskiego, co urągało poczuciu elementarnej przyzwoitości oraz godności oskarżonego. Wszystkie wnioski dowodowe złożone przez Kontryma odrzucono ${ }^{38}$.

W sądach tajnych oskarżony był na straconej pozycji, gdyż sądy te były sui generis spektaklem politycznym o zaplanowanym, z góry wiadomym finale. Wyroki faktycznie wydawali funkcjonariusze bezpieki, zaś rolą sądu było jedynie stwarzanie pozorów legalności i praworządności. O losie Kontryma nie przesądzili zatem świadkowie „przygotowani” wcześniej przez urząd bezpieczeństwa, chociaż należy stwierdzić, że żaden z nich nie potwierdził tezy oskarżenia, jakoby Kontrym znęcał się osobiście nad aresztowanymi i więzionymi komunistami, a jego osobiste sprawstwo było warunkiem skazania go na podstawie przepisów

\footnotetext{
${ }^{38}$ Z. Uniszewski, op.cit, s. 32.
} 
dekretu o faszyzacji życia państwowego. Jedynie wspomniana wyżej Walentyna Najdus zeznała, że była torturowana w gabinecie Kontryma, ale nie pamięta, czy Kontrym brał udział w znęcaniu się nad nią. Fakt braku dowodu osobistej winy oskarżonego nie przeszkodził Sądowi uznać jego sprawstwo i wydać wyrok skazujący. Wyrokiem wydanym przez sędziego Czesława Kosima w dniu 26 czerwca 1952 r. (sygn. akt IV 1K 60/52), Bolesław Kontrym został uznany winnym tego, że w okresie międzywojennym, służąc w Policji Państwowej, zwalczał i rozpracowywał organizacje komunistyczne, zaś samych komunistów przesłuchiwał, stosując niedozwolone metody śledcze. Za przestępstwo to Sąd skazał Kontryma na 10 lat pozbawienia wolności na podstawie art. 5 ust. 2 dekretu o odpowiedzialności za klęskę wrześniową i faszyzację życia państwowego. „Żmudzina” uznano także winnym popełnienia czynów opisanych w punkcie drugim aktu oskarżenia, tj. działania na rękę władzy państwa niemieckiego poprzez zwalczanie lewicowego ruchu antyfaszystowskiego i fizyczne wyniszczanie członków i sympatyków organizacji lewicowych, zwłaszcza PPR, GL-AL. Za przestępstwa te Sąd postanowił na podstawie art. 1 pkt. 2 i 7 ,sierpniówki” wymierzyć oskarżonemu łączną karę w postaci kary śmierci, pozbawienia praw publicznych i obywatelskich praw honorowych na zawsze oraz przepadek całego mienia. Jednocześnie - przypuszczalnie tylko po to, by zachować pozory niezależności i obiektywizmu - Sąd uwolnił Kontryma od części zarzutów z punktu drugiego aktu oskarżenia, tj. działalności w organizacji „Wachlarz” oraz kierowania likwidacjami działaczy lewicowych przez oddział ochronny "Sztafeta-Podkowa" 39 .

Uzasadnienie wyroku właściwie powtarza wszystkie tezy oskarżenia, posługując się przy tym ogólnikami i ideologicznymi sloganami oraz językiem agresywnym i pogardliwym, pełnym emocjonalnych inwektyw niedopuszczalnych dla cywilizowanego sądownictwa, ale jakże charakterystycznych dla procesów karnych okresu stalinowskiego, toteż przytoczę niektóre jego fragmenty. Uzasadnienie obejmuje takie stwierdzenia, jak np. „oślepiony nienawiścią do polskiego ruchu rewolucyjnego i ZSRR, w imię interesów obszarników i kapitalistów stał się [Kontrym - przyp. Ł.B.] zdrajcą Narodu Polskiego i bratobójcą" albo: „oskarżany Bolesław Kontrym prawie całe swe życie czynnie walczył z klasą robotniczą". W uzasadnieniu wyroku Sąd stwierdził ponadto - rażąco stroniąc od obiektywizmu i dając wyraz swemu upolitycznieniu - że ,społeczeństwo polskie widząc rosnącą z każdym dniem aktywność walki PPR z okupantem, darzyło lewicowe organizacje podziemne sympatią i zasilało ich szeregi. W szczególności PPR zdobywała poparcie wśród klasy robotniczej, ponieważ obok czynnej walki z okupantem, wierząc w potęgę i bratnią pomoc ZSRR - walczyła również o wyzwolenie społeczne, o władzę dla klasy robotniczej. Na skutek tego reakcja polska

${ }^{39}$ Wyrok (IPN GK 317/812). 
kierowana śmiertelnym strachem przed klasą robotniczą, w obliczu utraty władzy, walcząc przeciwko organizacjom antyfaszystowskim - staczała się coraz niżej, aż do współpracy z hitlerowskiej okupantem włącznie. W związku z tym podziemne organizacje prawicowe nie tylko, że nie prowadziły czynnej walki z okupantem, ale w zdradziecki, bratobójczy sposób walczyły z organizacjami lewicowymi”"40. W podobny ton uderzała prasa komunistyczna. „Trybuna Ludu” sprawozdanie z pierwszego dnia procesu Kontryma opatrzyła tytułem: „Siepacze z sanacyjnej »dwójki« spiskowali z hitlerowcami przeciw narodowi, przeciw niepodległości Polski" ${ }^{\prime 1}$.

Warto zaznaczyć, iż - jak wyżej pisałem - Bolesław Kontrym został aresztowany w związku z podejrzeniem o naruszenie art. 7 małego kodeksu karnego, a oskarżono go i skazano na podstawie art. $3 \mathrm{w}$ zw. $\mathrm{z}$ art. 5 ust. 2 dekretu o faszyzacji oraz z art. 1 pkt. 2 ,sierpniówki”, nie zawiadamiając go o zmianie kwalifikacji prawnej czynu ani na etapie postępowania przygotowawczego (śledztwa), ani w toku procesu sądowego. To rażące uchybienie proceduralne nie miało jednak dla sądu tajnego żadnego znaczenia, co kolejny raz dowodzi, że jego jedynym zadaniem była formalno-procesowa legalizacja mordu dokonanego przez UB na ewidentnie niewinnym człowieku. Miało natomiast znaczenie dla skazanego w I instancji, który oczywiście zdecydował się wyrok ten zaskarżyć, wnosząc rewizję do Sądu Najwyższego. Rozprawa rewizyjna SN miała miejsce 9 października 1952 r. Wyrok SN (sygn. akt III K 93/52), wydany przez sędziego Gustawa Auscalera (przewodniczącego składu orzekającego) oraz sędziów Mieczysława Dobromeskiego i Aleksandra Bachracha w obecności prokurator Generalnej Prokuratury PRL Pauliny Kern, nie uwzględnił wniosków skarżącego dotyczących uzupełnienia materiału dowodowego i powołania nowych świadków. Uchylił natomiast w części zaskarżony wyrok I instancji, po czym zmieniając jedynie kwalifikację prawną na art. 3 w związku z art. 7 „,sierpniówki”, ponownie skazał Kontryma na karę śmierci, pozbawienie praw publicznych i obywatelskich praw honorowych na zawsze oraz przepadek całego mienia na rzecz Skarbu Państwa, jako karę łączną na podstawie art. 31-34 kodeksu karnego ${ }^{42}$.

40 Ibidem, 3-4.

${ }^{41}$ W „Trybunie Ludu” nr 347 z 15 grudnia 1951 r. ukazał się artykuł pt. Wspólnie z gestapo organizowali w okresie okupacji morderstwa na patriotach-działaczach ruchu lewicowego. W artykule napisano, że ,akt oskarżenia przypomina, że w okresie gdy naród polski wzmagał bohaterską walkę z hitlerowskim okupantem o wyzwolenie narodowe i społeczne, gdy narody Związku Radzieckiego prowadziły zwycięskie boje z najeźdźcą - reakcyjne ugrupowania coraz bardziej pogłębiały politykę zdrady narodowej, politykę faktycznego współdziałania z okupantem”. „Trybuna Ludu” nr 349 z 17 grudnia 1951 r. o procesie Kontryma: „Szajka zdrajców, prowokatorów i morderców przygotowywała w Polsce reżim hitlerowskiego terroru".

${ }^{42}$ Wyrok (sygn. akt III K 93/52), s. 1-3. 
W uzasadnieniu SN zważył, że zarzuty rewizji oskarżonego są częściowo słuszne, jednak przyznał rację Sądowi I instancji, który - w ocenie SN - dokonał bezbłędnych i niebudzących wątpliwości ustaleń, polegających na tym, że „oskarżony był jednym z organizatorów zbrodniczej działalności »Start« [...] Organizacja ta dokonała fizycznego wyniszczenia członków organizacji lewicowych, skupiających się wokół PPR, prowadzącej walkę o wyzwolenie z faszystowskim okupantem i współpracującym z nim rodzimym obozem faszystowskim. Antynarodowa działalność oskarżonego nie ograniczyła się tylko do zorganizowania tej komórki. Instruował i kontrolował on jej działalność, w następstwie czego zamordowanych zostało około 50 działaczy antyfaszystowskich, a pozostałe materiały niewykorzystane w ramach »Startu« - przekazywano do wykorzystania niemieckim władzom bezpieczeństwa" ${ }^{43}$.

Ostatnią możliwością, jaką dysponował Kontrym, było napisanie prośby o łaskę do Rady Państwa. Prośbę taką napisał jego obrońca, adw. Maślanko, jednak jej treść stanowiła kolejny dowód rażąco nieetycznej postawy obrońcy względem swego klienta. Prośba o łaskę napisana w dniu 19 listopada 1952 r. zaczyna się od stwierdzenia, że ,skazany Bolesław Kontrym, syn pułkownika armii carskiej wychowany był w atmosferze reakcji i nienawiści do ruchów postępowych. W okresie międzywojennym był funkcjonariuszem policji i na tym stanowisku zwalczał skazany organizacje postępowe [...]. Niewątpliwie skazany Bolesław Kontrym od wczesnej młodości do zakończenia drugiej wojny światowej znajdował się w szeregach kontrrewolucyjnych”. Maślanko pominął wszystkie epizody z życiorysu Kontryma, o których, w ramach działania w interesie i na rzecz swego klienta, powinien był napisać (służba w Armii Czerwonej, walka $z$ Niemcami na frontach drugiej wojny światowej, udział w powstaniu warszawskim). Zamiast tego Maślanko ograniczył się do stwierdzenia, że po powstaniu Polski Ludowej Kontrym zakończył swą „kontrrewolucyjną” działalność. Prośbę o łaskę napisała do Bolesława Bieruta także żona Kontryma i jego syn Władysław ${ }^{44}$.

Wydaje się iż tym, co przesądziło o odrzuceniu prośby o łaskę przez Radę Państwa, mogło być pismo Sądu I instancji, w którym sędzia Kosim negatywnie zaopiniował prośbę skazanego, stwierdzając w uzasadnieniu tejże opinii, że „skazany Kontrym znaczną część swego życia poświęcił walce z rewolucyjnym ruchem robotniczym. Walka ta miała szczególnie w okresie okupacji wyraźne elementy faszystowskie. Skazany Kontrym z zimną krwią wespół z oprawcami hitlerowskimi przykładał rękę do mordowania najlepszych synów klasy robotniczej. $\mathrm{Z}$ jego zachowania w czasie kilkudniowej rozprawy sądowej należy przyjąć, że

\footnotetext{
43 Ibidem.

${ }^{44}$ Sygn. akt IV K 60/52, karta nr 174.
} 
w jego psychice nie zaszły żadne zmiany, które by wskazywały na jakąkolwiek skruchę za zbrodnie, które popełnił. Skazany wprost cynicznie, mimo oczywistych dowodów jego zbrodni, nie tylko, że nie przyznawał się do tych zbrodni, ale usiłował przedstawić siebie jako gorącego patriotę. Z tych względów Kontrym, zdaniem Sądu Wojewódzkiego, na łaskę nie zasługuje”. Do opinii tej przychylił się także SN. W piśmie Generalnej Prokuratury - Biura Ułaskawień z dnia 31 grudnia 1952 r. skierowanym do Sądu I instancji zawiadomiono, że w dniu 27 grudnia 1952 r. Rada Państwa nie skorzystała z prawa łaski wobec skazanego Bolesława Kontryma. Wyrok śmierci wykonano w więzieniu mokotowskim przez powieszenie w dniu 2 stycznia 1953 r. około godziny 20:3045. Szczątki majora Kontryma zostały odnalezione przez IPN dopiero w 2014 r. Warto dodać, że w tej samej celi śmierci, w której stracono Kontryma, 24 lutego 1953 r., a więc półtora miesiąca później, życie zakończy inny wielce zasłużony polski oficer, jeden z najwybitniejszych dowódców AK, gen. August Emil Fieldorf, ps. „Nil” - kolejna ofiara sądów tajnych ${ }^{46}$.

Na fali gomułkowskiej odwilży w 1956 r. postanowiono zbadać działalność orzeczniczą sekcji tajnych, co w przypadku Kontryma skutkowało wydaniem przez Sąd Najwyższy w dniu 31 sierpnia 1957 r. postanowienia o wznowieniu postępowania w jego sprawie. U podstaw postanowienia Sądu legło ustalenie, że Kontrym był faktycznie pozbawiony obrony i bezskutecznie wnosił o ustanowienie obrońcy z wyboru. Proces rehabilitacyjny „Żmudzina” toczył się przed tym samym sądem, który skazał go w I instancji (IV Wydział Karny Sądu Wojewódzkiego dla $\mathrm{m}$ st. Warszawy). Na trzech rozprawach (5, 15 i 30 listopada 1957 r.) przesłuchano tych samych świadków, którzy zeznawali przeciw Kontrymowi w podczas rozprawy w I instancji w 1952 r. Świadkowie ci odwołali swe wcześniejsze zeznania, thumacząc się stosowanym wobec nich przymusem fizycznym i psychicznym. Wyrok rehabilitacyjny zapadł w dniu 3 grudnia 1957 r. Sąd pod przewodnictwem sędziego A. Derkacza wraz z ławnikami J. Jurkiewiczem i Z. Grollem w obecności prokuratora Generalnej Prokuratury PRL Stanisława Krygiela, uniewinnił oskarżonego Kontryma z zarzucanych mu aktem oskarżenia przestępstw (sygn. akt IV K 157/57) ${ }^{47}$.

Warto zaznaczyć, że w uzasadnieniu wyroku Sąd poddał analizie stronę podmiotową i przedmiotową przestępstwa określonego w art. 3 dekretu o faszyzacji życia państwowego. Powołując się na orzeczenie SN z dnia 7 marca $1957 \mathrm{r}$.

${ }^{45}$ Akt zgonu Bolesława Kontryma sporządzony przez Urząd Stanu Cywilnego Warszawa-Mokotów na podstawie pisemnego doniesienia naczelnika więzienia mokotowskiego z dnia 17 stycznia 1953 r. (nr akt 2972/51).

46 W. Pasek, op.cit., s. 340-342.

${ }^{47}$ Z. Uniszewski, op.cit., s. 35-36. 
(I K.Rn. 1055/56) Sąd zaznaczył, że nie każde, a tylko świadome i zamierzone działanie na korzyść ruchu faszystowskiego lub narodowo-socjalistycznego mieści się z granicach dyspozycji art. 3 wspomnianego wyżej dekretu. Ponadto, na podstawie orzeczenia SN z dnia 31 lipca 1957 r. (I K.Rn. 630/57), Sąd skonstatował, iż rozstrzyganie w sprawach publicznych na rękę ruchowi faszystowskiemu lub narodowo-socjalistycznemu musi przybrać postać zasadniczej koncepcji politycznej zrodzonej na najwyższym szczeblu państwowym, nie zaś czynu realizującego taką koncepcję. Przyjęcie tego drugiego sposobu rozumowania implikowałoby absurdalną konieczność pociągnięcia do odpowiedzialności karnej absolutnie wszystkich urzędników administracji II RP wykonujących przecież określoną przepisami prawa politykę państwa. W uzasadnieniu wyroku Sąd skonkludował, że ,zebrany w toku obecnego przewodu sądowego materiał dowodowy z przesłuchania szeregu świadków nie tylko nie potwierdza ustaleń poprzednich orzeczeń Sądów Wojewódzkiego dla m. st. Warszawy i Najwyższego, lecz często w sposób diametralnie różny przemawia za brakiem dowodów winy oskarżonego Bolesława Kontryma". Sąd przyznał także, że Kontrym był ,jednym z najofiarniejszych członków Armii Krajowej, a uniewinnienie stanowi dlań akt jego pełnej rehabilitacji i przywraca mu honor i cześć, a rodzinie jego moralną satysfakcję"48. Nie odmawiając Sądowi słuszności orzeczenia i jego uzasadnienia, należy na koniec stwierdzić, że akta śledztwa i procesu sądowego Bolesława Kontryma pozostały niedostępne dla jego rodziny aż do 1982 r., w którym synowi Kontryma, Władysławowi pozwolono zapoznać się z częścią dokumentów sprawy.

Sprawa Bolesława Kontryma stanowi jeden z wielu przykładów działalności tzw. sądów tajnych. Tragiczny koniec tego zasłużonego dla Polski żołnierza dobitnie udowadnia, że sądy te były właściwie wydzieloną, quasi-sądową gałęzią organów bezpieczeństwa, które nadzorowały zarówno postępowanie przygotowawcze, jak i przewód sądowy, potwierdzając tym samym z góry założone przez siebie tezy. Każdy bowiem etap procesu był szczegółowo wyreżyserowany przez funkcjonariuszy bezpieki, którzy, rękoma dyspozycyjnych sędziów z udziałem zaufanych obrońców i prokuratorów, realizowali od początku zaplanowaną operację eliminacji przeciwników politycznych. Wiedzę o degeneracji tego szczególnego rodzaju sądownictwa i wszystkich jego nieprawidłowościach zawdzięczamy dorobkowi Komisji Specjalnej dla Oceny Działalności tzw. Sekcji Tajnej utworzonej w 1956 r. przez ówczesną minister sprawiedliwości Zofię Wasilkowską. Komisja zapoznała się aktami kilkuset spraw rozpatrzonych przez sądy tajne i w niemal każdej z nich dopatrzyła się rażących naruszeń prawa i procedur, chociażby pra-

${ }^{48}$ Wyrok (sygn. akt IV K 157/57), s. 7-8. 
wa do obrony czy prawa do jawności rozprawy. Niestety, ponure wnioski z oceny działalności sądów tajnych nie pociągnęły za sobą adekwatnych konsekwencji wobec osób winnych naruszeń prawa i nie skutkowały pociągnięciem ich do odpowiedzialności karnej. Było to wynikiem wstrzymania przez Gomułkę w 1957 r. tendencji liberalizujących system ${ }^{49}$.

\author{
THE TRIAL OF BOLESŁAW KONTRYM. THE JUDICIARY \\ IN THE POLISH PEOPLE'S REPUBLIC BETWEEN 1944 AND 1955: \\ AN OUTLINE OF THE ISSUE
}

\begin{abstract}
This article acquaints the reader with the issue of the common and military judiciary in Poland in the age of the Stalinism. Drawing upon court records, the author presents the criminal trial of Boleslaw Kontrym a.k.a. "Żmudzin", a pre-war police officer, soldier of the Home Army and a freedom fighter during the Warsaw Uprising. Subsequently, he was executed by the Communists during the first years of the Polish People's Republic. This highly meritorious independence activist became a victim of the so-called secret courts conducted by the Communists, which were also known as secret sections. The judicial activity of these courts is characterized in the following article on the basis of the court records pertaining to the presented criminal trial.
\end{abstract}

\title{
PROCES DE BOLESLAW KONTRYM. SYSTEME JUDICIAIRE EN REPUBLIQUE POPULAIRE DE POLOGNE EN 1944-1955: APERÇU DU PROBLEME
}

\section{Resumé}

L'article présente aux lecteurs les problèmes des tribunaux de droit commun et tribunaux militaires en Pologne stalinienne ; il donne comme exemple le procès pénal du major Bolesław Kontrym surnommé «Żmudzin », agent de police d'avant-guerre, soldat de l'AK (l'Armée de l'intérieur) et insurgé de Varsovie, tué par les communistes au cours des premières années de la République populaire de Pologne. Ce militant indépendantiste hautement apprécié a été victime des soi-disant tribunaux secrets (sections secrètes). En s'appuyant sur l'examen des dossiers judiciaires de cette affaire pénale, l'auteur a analysé le fonctionnement de ces tribunaux.

${ }^{49}$ Zob. S. Ehrlich, M. Kulczycki, J. Litwin, Z. Opuszyński, J. Potępa, S. Zawadzki, Zza kulis sekcji tajnych, „Gazeta Prawnicza” nr 17-22, 01.09.1989 r. 